\title{
Teaching Business English to Future Economists
}

\section{Using a Multimedia Textbook}

\author{
Oksana P. Bykonia ${ }^{1}$, Iryna V. Borysenko ${ }^{1}$, Iryna M. Zvarych ${ }^{2}$, Tetiana V. Harbuza ${ }^{2}$ \& Myroslava V. Chepurna ${ }^{3}$ \\ ${ }^{1}$ Department of Foreign Languages, Academy of the State Penitentiary Service, Chernigiv, Ukraine \\ ${ }^{2}$ Department of Modern European Languages, Faculty of International Trade and Law, Kyiv National University of \\ Trade and Economics, Kyiv, Ukraine \\ ${ }^{3}$ Department of Foreign Languages, Faculty of Humanitarian Technologies, Cherkasy State Technological University, \\ Cherkasy, Ukraine
}

Correspondence: Oksana P. Bykonia, Department of Foreign Languages, Academy of the State Penitentiary Service, 34, Goncha Street, Chernigiv, 14000, Ukraine. E-mail: oksanabikonya@ ukr.net

Received: June 21, 2019

doi:10.5430/ijhe.v8n4p115
Accepted: July 16, 2019

Online Published: July 17, 2019

URL: https://doi.org/10.5430/ijhe.v8n4p115

\begin{abstract}
The purpose of the study is to examine and evaluate the impact the "flipped classroom" model-based learning environment accompanied by multimedia-based textbook entitled "English through Soft Skills" provides for the learning styles of the university students majoring in Economics. The study sought to identify tangible (seemingly measurable) and intangible (difficult to measure) gains the "flipped classroom" learning model brought to both students and instructors. A multimedia textbook "English through Soft Skills" was developed for the study. A multi method approach was used to gather feedback and quantitative methods were used to analyze the data. Specifically, Covariance-based Structural Equation Modeling (SEM) software as SPSS AMOS and Textalyzer were used to process the students' responses to survey questions. The results reported a shift in student preferences in learning, including a greater desire to engage independently with computer-assisted work, quicker problem solving, increased motivation to study, and improved time management and lifelong learning skills. Additionally, there was a shift in teaching approaches of the instructors, namely from a teacher-centered to a student-centered approach. The study may better inform building the learning process for the students with limited learning opportunities or studying the distance learning model. Despite the experimental group involving only the students majoring in Economics, this methodology could be applicable to teaching English for Specific Purposes to other majors, such as: Business, International Relations, Psychology, Law. The research is advancing the knowledge of integration multimedia tools into teaching, and specifically the use of multimedia textbooks in the "flipped classroom" settings to deliver Business English course to the students majoring in Economics
\end{abstract}

Keywords: tertiary school, teaching business English, "flipped classroom" model, multimedia-based textbook

\section{Introduction}

The use of multimedia tools in teaching has proven to enhance teaching effects (Almarabeh et al., 2015; Gunawardhana \& Palaniappan, 2016b). It has changed the ways instructors and researchers explore educational concepts as it provides convenience, drastically changes the learning experience of students, and it increases student involvement in the learning process. Multimedia tools support the teacher by supplying additional educational elements to students' cognitive process (Gunawardhana \& Palaniappan, 2016a), therefore, using a multimedia textbook as a tool to teach Business English to future economists is worthy of discussion.

This research was inspired by the easy-to-adjust nature of the multimedia textbook-based "flipped classroom" model as it fits ESP (English for Specific Purposes) and CLIL (Content and Language Integrated Learning) approaches to teaching English Language at tertiary schools. A "flipped classroom" teaching method is often difined as the inverted classroom, or to put it simply, the flip. This teaching method or model is related to the concept of creating a hybrid, or blended learning and problem-based learning environment to engage students in active learning through the use of new technologies (Arnold-Garza, 2014). The latter moves the lecture outside of class and enables using class time more efficienly dedicating it to the practical application assignments (Educause, 2012). Therefore, flipped learning is 
viewed as a pedagogical approach based on reversing the roles of individual and group space resulting the latter is transformed into a dynamic, interactive learning environment guided by the educator and in which students are supported by peers as apply concepts and participate creatively in the subject matter (Giannakos et al., 2018).

In view of the above, the "flipped classroom" model is likely to best suit the state policy in English Language teaching in Ukraine (Bolitho \& West, 2017) due to a number of its advantages (Arnold-Garza, 2014), such as: the efficient use of time during the class, provision the students with a more interactive learning environment, provision of increased student and teacher personal collaboration and interaction, shifting responsibility for learning from a teacher to a student, and consideration of students' learning styles.

Integrating multimedia tools into teaching is being widely discussed by scholars (Babiker, 2015; Udim \& Etim, 2016; Norlis et al., 2018), but this discussion is still rather theoretical. For this reason, many aspects of the use of interactive multimedia tools used for teaching purposes are open to discussion (Thamarana, 2016). It was found a limited number of targeted studies such as the use of multimedia textbooks in the "flipped classroom" settings to deliver Business English course to the students majoring in Economics. Additionally, while commonly a "flipped classroom" model is associated with watching lectures preliminary recorded for students to prepare for the following class, Giannakos et al. claim that the use of lecture videos is not indispensable (Giannakos et al., 2018). Using online simulations or demonstrations, in-video quizzes or guided reading etc. are other options. Thus, it matters little how the new material is introduced to the the students, but it matters a lot that they come to class "equipped" to engage in active learning.

This article examines and evaluates a change in the learning styles of the students majoring in Economics where the "flipped classroom" model-based learning environment accompanied by multimedia-based textbook entitled "English through Soft Skills" is applied.

\subsection{The "Flipped Classroom" and Multimedia Textbook}

Both the "Flipped classroom" learning model and multimedia textbook can be viewed from two perspectives: technical and instructional. Technically, the "Flipped classroom" is addressed as the type of "blended learning" approach, which "has garnered more media attention, reported more tangible results, and gained the support of more educators" (Panopto, 2015). The "flipped classroom" mode focuses on practical application rather than passively listening to a lecture, which optimizes class time use (Flip Learning, 2015). There are, at least, seven tested and cited flip classroom concepts which are used in schools and tertiary settings, that encourage instructors to use different styles of teaching, diverse information sources, and a wide range of student interaction modes. They are the standard inverted classroom, the discussion-oriented flipped classroom; the demonstration-focused flipped classroom, the faux-flipped classroom, the group-based flipped classroom, the virtual flipped classroom, flipping the teacher model (Panopto, 2017). With regard to teaching ESP (English for Specific Purposes) to the students majoring in Economics, it was found the discussion-oriented, the faux-flipped and the group-based models of flipped classroom to be of particular interest for our study as they provide the context for the further discussions, they allow revision of what has been learnt at the student's own pace, these models involve students in knowledge exchange. Additionally, the models extend time to dedicate to classroom discussions which provides students with more purposeful speaking and writing practice, they increase both the quantity and quality of teacher-student and student-student collaboration and students' academic performance. The latter was experimentally proved by Zhonggen \& Wang (2016) when delivering the courses in English writing and by Cabi (2018), who used a "flipped classroom" model in English Language Teaching and Turkish Language Teaching Programs.

Form the instructional perspective, scientists report that the "flip classroom" model satisfies their pedagogical needs. While Findlay-Thompson \& Mombourquette (2014, p. 65) stated flipped course met their needs in "application, analysis, and evaluation", Wiginton (2013) and Cabi (2018) asserted that the model accelerates student responsibility, motivation, self-organisation, and the skills of research-based and autonomous learning.

A key technical perspective of the multimedia textbook is an interactivity component and its composition including a content and graphics, the parts like audio, multi-media, interactive elements (Gu et. al., 2014; Krotký \& Honzíková, 2013) accompanied by gamification elements (Jackson, 2016). Amaral (2014) classifies interactivity parenthesis here as a three-level-controlled by the user environment. The first level is reactive which is a low interaction supposing the User to make choices pre-defined by the producer. The second level is coactive allowing the User to exercise control over choices and take sequential steps. The third level is proactive providing a teacher-student or student-student interactivity of a high level with the opportunity for the User to make changes to the configuration or the content so that the User acts as a producer of a content or the structure. 
The primary purpose of multimedia textbooks, which is software, is educational. For this reason, they should involve the components and the structural elements typical for a paper-based textbook. It terms of teaching ESP, multimedia textbooks should combine texts, audio and video, specifically structured activities with software components like an easy navigation, animation, hyperlinked glossary, internal and external text links, visualized data, searching etc. (Krotký \& Honzíková, 2013).

From the instructional perspective, multimedia textbooks - contrary to the three suppositions of Cognitive Theory of Multimedia Learning (CTML) (Amaral, 2014; Park et al., 2014) holding that: people use channels (visual and verbal) to perceive information separately; processing of information is limited by the channel; the multimedia-based learning is only possible when the student is self-involved in selecting, organizing, and integrating the obtained information with the previous knowledge - are leading students towards learning as long as the materials are designed and presented by the teacher appropriately (Amaral, 2014). In the view of the above, "situational interest", "positive emotions", or "confusion" (Leutner, 2014) have been revealed to have impact on cognitive processing and learning outcomes when learning through multimedia tools. Additionally, efficiency of material comprehension can be fostered by positive emotional design (Park et al., 2014).

Gamification, like simulating situations (Negotiations, Meetings, Telephone conversations), is another powerful interactive element which, in ESP settings, develops not only language skills but strategic thinking, culture awareness, intuitive self-control (Khaleel et. al., 2016).

\section{Materials and Methods}

This research relies on empirical and statistical methods used for conducting an experimental study of some aspects of teaching business English to the economists-to-be using multimedia textbooks. To meet the research objective, this study used a mixed-methods approach based on collection quantitative data to obtain the overall picture of a problem and qualitative data to reveal explanatory details. The flipped classroom and traditional teaching use resulted data were considered independent variables of the research while students' academic achievements were the dependent variable.

The study was a continuous flow of three stages: (1) empirical - to study the current state of teaching Business English at tertiary institutions using the multimedia-based tools, developing and piloting a content of a multimedia textbook; (2) experimental - to do placement tests, needs analysis questionnaires, face-to-face sessions, tutorials, project-based learning conducted both traditionally (offline), and with the multimedia book to have been integrated; (3) analytic - to process the experimental data collected.

Empirical surveys were conducted among the teachers/tutors and students majoring in Economics to investigate the state of teaching Business English. 1241 first year students and teachers/tutors were surveyed at universities located in Dnipro (Alfred Nobel University), Zhytomyr (Zhytomyr State University named after Ivan Franko), Kyiv (Kyiv National Economic University, named after Vadym Hetman), Lvyv (Lviv University of Business and Law), Nizhyn (Nizhyn Agrotechnical Institute of the National University of Bioresources and Natural Resources of Ukraine), Odesa (Odessa State University of Internal Affairs), Poltava (Poltava University of Economics and Trade), Ternopil (Ternopil National Economic University), and Chernihiv (Chernihiv State Institute of Law, Social Technologies and Labour) to explore the state of ESP teaching. Due to application of exclusion criteria list such as: student age, major, English learning purpose, teacher/tutor willingness to implement a flipped class model and multimedia textbook it their studies, location of the institution, the population was reduced by 1133 people and it was obtained the population size of 108 people. In order to determine the sample size to ensure the quality and reliability representativeness, the Sample Size Calculator (Google Apps) was used. It was established that $\mathrm{N}$ (population size) = 108 , and $\mathrm{e}=.05$ at $95 \%$ confidence level. Therefore, the required sample size obtained was 86 people and this number was used to form the experimental group for this study.

Therefore, the experimental group involved 87 (49 males and 38 females) students who were doing the course in Economics and Social studies and were in their first year at the Academy of the State Penitentiary Service, which meets the requirements for ensuring sufficient volumes of sample population in the study.

At the pre-experimental stage, there were studied the preferences in the learning activities of the experimental group students, their needs and results of the placement test and final test in English for Special Purposes Course.

Concurrently, the development and piloting a multimedia textbook entitled "English through Soft Skills" occurred comprising of five modules: Business communication (Introducing yourself, Business interview, Applying for a job (writing Cover Letters, CV)); Business telephone calls (Making appointments, Messaging, Faxing); Business meeting (Business meeting's process, Business meeting's documentation (writing agenda, reports, essays); Business 
presentation (Presentation: stages, Writing reports (essays) of presentation); Business talks/negotiations (Business talks/negotiations: stages, E-mailing and reports in negotiating, making up Business contracts and agreements). Throughout 2017-2018, the adapted methods were applied (Adeniyi \& Yusuf, 2016; Krotký \& Honzíková, 2013), module-structure-design methodology borrowed from Behnke (2016), Zhang \& Yang (2017) and involved IT specialists to design each module in our multimedia-based textbook using such multimedia software as iSpring, Director, Photoshop, Cool Edit Pro, Video Studio, Active Textbook, etc.

The questionnaire on preferences in learning consisted of four options to choose among. Those were to explore whether a student a) likes working in the class under the teacher's control, b) gives reference to study using written materials independently, c) inclines to computer-assisted work independently or d) enjoy doing exercises and tasks cooperatively (in mini groups).

Students' Needs Analysis Questionnaire used closed-ended and semi-closed-ended questions with suggested options the students should choose among. Those were aimed to discover 1) the purpose a student studies English for; 2) the areas the student will use it the most; 3 ) the students' idea of the use of the coursebook (as a reference point or to do every exercise in it); 4) the students' idea of the use of lesson time; 5) the students' idea of being assigned to do the hometask.

The experimental stage was divided into two sub-stages: the first stage was based on a traditional mode (offline) of interaction (face-to-face, classroom activities), while the second stage was based on the "flipped classroom" model. The greatest proportion of their learning workload was supposed to be done as a self-study assignment (see the design of the study in Table 1). The students' learning outcomes were measured by administering an achievement test before and after the treatment.

Table 1. Design of the study

\begin{tabular}{l|c|c|l}
\hline \multicolumn{1}{c|}{ Pre-treatment stage } & \multicolumn{2}{|c|}{ Treatment stage (2 semesters) } & \multicolumn{2}{c}{ Post-Treatment stage } \\
\hline Unbiased assignment, & 1 st semester & $2^{\text {nd }}$ semester & Achievement Test \& \\
Students' Needs & Traditional mode & "Flipped classroom" model-based mode & Course Satisfaction \\
Analysis Survey \& & & & Questionnaire \\
Achievement Test & & & \\
\hline
\end{tabular}

The necessary two-stage-based learning environment was designed for the students to perform the treatment. The general features of the traditional and a "flipped classroom" model-based learning environments are shown in Figure 1.

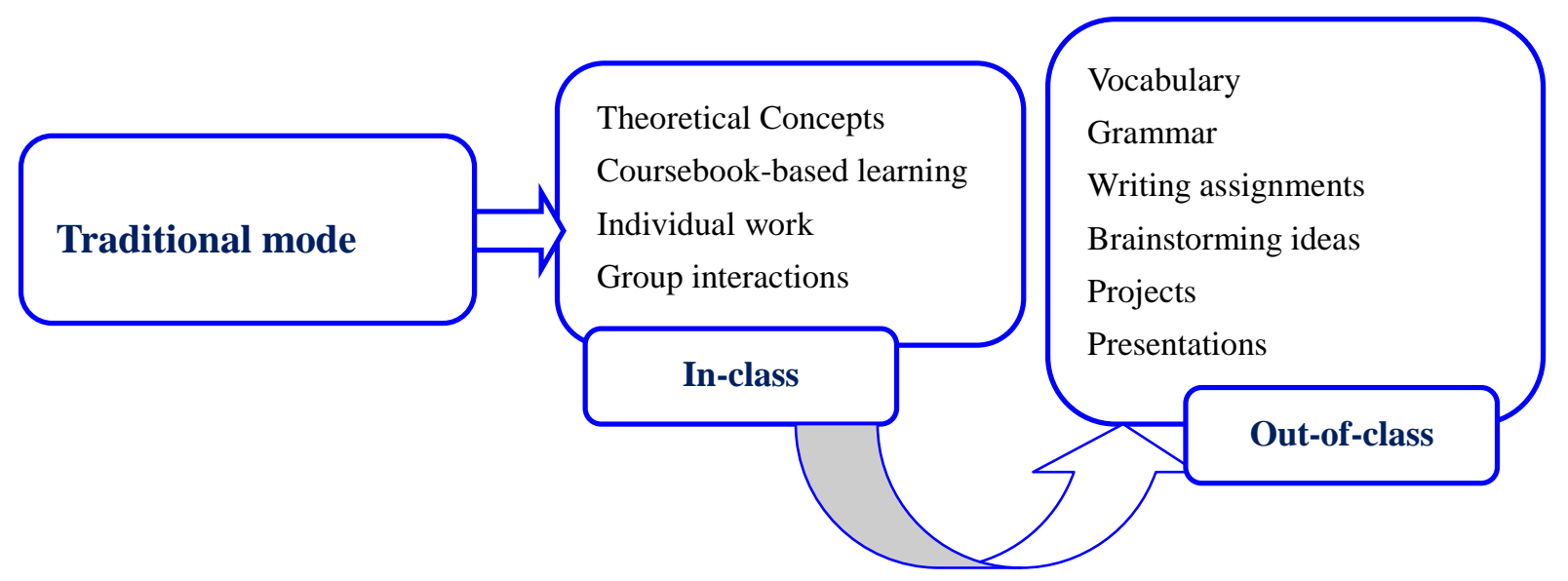




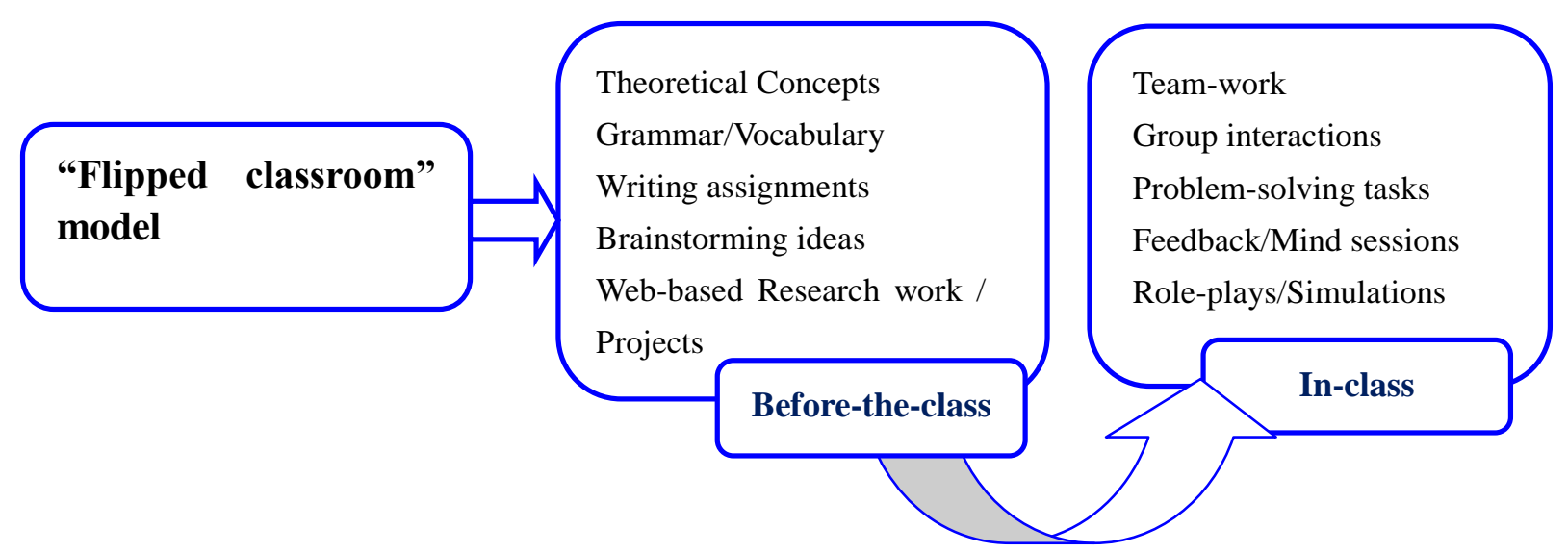

Figure 1. Features of features of a traditional mode and "flipped classroom" model-based learning environments.

At the after-experimental (analytic) stage (2018 - beginning of 2019), there were studied the results of experimental group students obtained in their final test in English for Special Purposes Course (Business English), Course Satisfaction Questionnaire responses and used the qualitative method to process the data collected experimentally.

The above questionaire used five closed-ended questions asking 1) whether the the learning mode met the student's expectations; 2) whether the course content was adequate to the student's professionalism-related needs; 3 ) whether the student benefited professionally from doing Business English course accompanied by media textbook; 4) wthere the instructor delivered the course using a variety of methods and activities; 5) whether the instructor challenged the student to do your best in learning.

Covariance-based Structural Equation Modeling (SEM) software as SPSS AMOS and Textalyzer were used to process the students' responses to survey questions and direct quotations provided from the participants' responses semi-closed-ended questions.

\section{Results}

The purpose of this study was to experimentally examine and evaluate the extend the "flipped classroom" model-based learning environment accompanied by multimedia-based textbook entitled "English through Soft Skills" impacts on learning styles of the students majoring in Economics. The below diagram illustrates the model (Figure 1).

\begin{tabular}{|c|c|}
$\begin{array}{c}\text { Before the Class } \\
\text { (Online) } \\
\text { Multimedia textbook- } \\
\text { supported flipped mode } \\
\text { Vocabulary } \\
\text { Grammar }\end{array}$ \\
While the Class \\
(Offline) \\
Problem-solving tasks \\
Case studies \\
Presentations \\
Theotings \\
Writing assignments \\
Brainstorming ideas \\
Web quests/web quizzes
\end{tabular}

Figure 2. Multimedia textbook-based "Flipped classroom" learning model (distribution of the activities)

Overall, the students reported progression in their writing skills, perception of non-adapted texts, and spoken response speed in the interactions (Business meetings, Negotiations, Presentations) along with the skills of summarising, paraphrasing, deducing, synthesising and systemising of information. 


\subsection{Graphical Representation of the Results}

Results clearly suggest that students have experiences a dramatic change in perception of benefits of learning through self-performing multimedia-based assignments (see Table 1).

Table 2. Shift in student preferences in learning

\begin{tabular}{|c|c|c|}
\hline \multirow[b]{2}{*}{ Preferences in Learning } & Pre-experimental stage & \multirow{2}{*}{$\begin{array}{l}\text { After-experimental stage } \\
\text { The "flipped classroom" model with } \\
\text { multimedia-based textbook }\end{array}$} \\
\hline & $\begin{array}{l}\text { Traditional learning/teaching } \\
\text { model }\end{array}$ & \\
\hline $\begin{array}{l}\text { learning in the class under the } \\
\text { teacher's control }\end{array}$ & $24 \%$ & $9 \%$ \\
\hline $\begin{array}{l}\text { using written materials } \\
\text { independently }\end{array}$ & $28 \%$ & $10 \%$ \\
\hline $\begin{array}{l}\text { doing computer-assisted work } \\
\text { independently }\end{array}$ & $37 \%$ & $67 \%$ \\
\hline $\begin{array}{l}\text { doing assignments cooperatively } \\
\text { (in mini groups)." }\end{array}$ & $11 \%$ & $14 \%$ \\
\hline
\end{tabular}

In the view of the above, the experimental group students found interactive methods like web-cases, web-quests, non-adapted video and audio materials effective as they developed their job skills like problem solving, increase motivation to solve the problem, time management skills, and lifelong learning skills. The results obtained from both the final test in English for Special Purposes Course (Business English), Course Satisfaction Questionnaire proved a potential of the "flipped classroom" model accompanied by multimedia textbook to bring positive changes in terms of student involvement, their commitment, motivation and practical use of what has been learnt (see Table 2).

Table 3. Shift in aspects of learning

Learning aspects Traditional learning/teaching

The "flipped classroom" model with model multimedia-based textbook

\begin{tabular}{lll}
\hline Involvement & $43 \%$ & $81 \%$ \\
\hline Commitment & $45 \%$ & $63 \%$ \\
\hline Motivation & $49 \%$ & $79 \%$ \\
\hline Practical application & $32 \%$ & $68 \%$ \\
\hline
\end{tabular}

With regard to the impact of "flipped classroom" model with multimedia-based textbook to the shift in learning aspects, the above table looks suggestive for this study. When asked how much time they studied outside the classroom, 7 students repored that they dedicated one-two hours to their studies outside the classroom, 6 students spent three-four hours, the other students $(74(81 \%))$ - four-five hours. When asked about the positive aspects of the "flipped classroom" model combined with multimedia-based textbook, 69 (79\%) students stressed the fact that a group work in the class was more motivating than doing activities individually at home, in contrast to 18 (21\%) students who stated that they were challenged with the content or had procrastination problems or did not like this teaching approach. The implication from this seems to be that the model crucial contributes to forming both student preferences and learning aspects.

It is still a challenge to face for the English language teachers of the tertiary institutions of Ukraine to use technology to build the students' learning process on which limits students' learning opportunities. University teachers/lecturers mostly use classroom activities, but we found that, though less commonly used, paper-based materials are becoming less popular than electronic ones. Moreover, it is a problem that the teachers/lecturers of tertiary institutions in Ukraine prefer using reproductive activities, as their students lack motivation to study and they force them (not motivate) to study. 


\section{Discussion}

The multimedia textbook-based "flipped classroom" learning model is a competency-based one as it focuses on the variety of activities aiming at intriguing and retaining the learner's concentration and maintain his/her interest and motivation to learn.

The model also intends to develop learner's skills for life-long learning, to suit learning styles of every student. The methods used to assess the progress of student in learning under the 'flipped classroom' do not directly assess the performance resulted from the flip. In this study, we identified tangible (seemingly measurable) and intangible (difficult to measure) improvements. Final test grades in English for Special Purposes Course (Business English), results of quizzes, projects, responses from the Course Satisfaction Questionnaire were the ones considered to be tangible improvement indicators. Students' engagement, their confidence, self-reliance, commitment, motivation were, in our view, intangible factors (improvements) but they were important learning progress indicators.

In the view of the above, the assessment method used in this study is almost identical to a method for assessment used Boucher et al. (2013), Findlay-Thompson \& Mombourquette (2014). They compared grade data obtained from exams, tests quizzes to measure the learning progress of their students.

This study proved that teaching Business English to students majoring in Economics on the basis of multimedia textbook-based "flipped classroom" learning model would result in improving students' overall learning performance as they consume and save their time, get instant feedback and assessment, and have an opportunity to experience self-paced learning.

There are some methodological peculiarities of the use of multimedia textbook in teaching Business English. These are as follows:

- the use of multimedia textbook should be aimed at meeting not only the educational but didactic requirements;

- a multimedia textbook design is supposed to be interactive;

- a multimedia textbook content should be based on the activities, such as: video, audio, interactive games, quizzes, etc;

- a multimedia textbook should provide the hyperlinks to the reference sources.

Overall, our experimental output proved that students' educational gains form learning Business English through application of multimedia textbook-based "flipped classroom" learning model are more apparent and far greater than those obtained through a traditional educational model. Moreover, providing learners with opportunities to satisfy their increasing learning needs educational institutions are able to strengthen their image and to increase attractiveness among potential students.

\section{Conclusion}

The multimedia textbook-based "flipped classroom" learning model of teaching Business English to the students majoring in Economics is able to bring distinct benefits for both students and instructors. This model focuses on efficient use of time in the class, encourages both stakeholders of educational process to a deeper interaction. It pushes students to taking responsibility for their learning outcomes and accommodates them with different learning styles, involves them in problem-based learning. The model engages students' critical thinking, research and problem solving skills.

Thus, the above model allows taking a shift from a teacher-centered approach with a focus on linguistic and socio-cultural competencies to a student-centered approach that aims at developing English communicative competency. In this regard, teaching Business English at the higher educational establishments changes form merely being a knowledge transfer of memorizing Business English vocabulary, grammar rules in different situations in Business English and writing translations to solving true-to-life, problem-based cases and acquiring professionalism-related skills.

\section{Limitation and Study Forward}

The major limitation to this study is a single institution involvement. The age of the experimental group students seems to be another limitation - first and second year students of Bachelor programmes were involved. The major (specialisation) of the students can be also regarded as a limitation - students majoring in Economics were a experimental group while methodology is applicable to other majors, such as: Business, International Relations, Psychology, Law, etc. The researcher bias might be regarded a limitation as well as some of the members of our research group were involved in the course design. 


\section{Acknowledgement}

This research was performed with the involvement of the English language teachers from the universities in Dnipro, Zhytomyr, Kyiv, Lvyv, Nizhyn, Odesa, Poltava, Ternopil, Chernihiv (Ukraine) and Prague (Czech Republic). The English language teachers from the Academy of the State Penitentiary Service participated in research as well. Additional research with different participants (students or university lecturers) could fruitful the data. A more extended quantitative study could contribute to this investigation.

\section{References}

Adeniyi, A. E., \& Yusuf, H. O. (2016). Effects of computer assisted instruction on independent learning skills of Economics students in secondary schools in Kaduna state, Nigeria. European Journal of Alternative Education Studies, 1(2), 85-92.

Amaral, R. (2014). Textbook and technology: an analysis of multimedia learning in Brazil. Proceedings of the International Conference on Mathematics Textbook Research and Development 2014 (pp. 147-152). Southampton, UK.

Almarabeh, H., Amer, E. F., \& Sulieman, A. (2015). The Effectiveness of Multimedia Learning Tools in Education. International Journal of Advanced Research in Computer Science and Software Engineering, 5(12), $761-764$.

Arnold-Garza, S. (2014). The flipped classroom teaching model and its use for information literacy instruction. Communications in Information Literacy, 8(1), 7-22. https://doi.org/10.15760/comminfolit.2014.8.1.161

Babiker, M. (2015). For Effective Use of Multimedia in Education, Teachers Must Develop their Own Educational Multimedia Applications. The Turkish Online Journal of Educational Technology, 14(4), 62-68.

Behnke, Y. (2016). How textbook design may influence learning with geography textbooks. Nordidactica - Journal of Humanities and Social Science Education, 1, 38-62.

Bolitho, R., \& West, R. (2017). The internationalization of Ukrainian universities: the English language dimension. Retrieved https://www.teachingenglish.org.uk/sites/teacheng/files/Pub-UKRAINE-REPORT-H5-EN.pdf

Boucher, B., Robertson, E., Wainner, R., \& Sanders, B. (2013). “Flipping” Texas State University's physical therapist musculoskeletal curriculum: Implementation of a hybrid learning model. Journal of Physical Therapy Education, 27(3), 72-77. https://doi.org/10.1097/00001416-201307000-00010

Cabi, E. (2018). The Impact of the Flipped Classroom Model on Students' Academic Achievement. International Review of Research in Open and Distributed Learning, 19(3), $202-221$. https://doi.org/10.19173/irrodl.v19i3.3482

Educause. (2012). 7 things you should know about flipped classrooms. Retrieved http://net.educause.edu/ir/library/pdf/ ELI7081.pdf

Flip Learning. (2015). Changing how you use Class Time is a Primary Benefit of the \#FlipClass. Retrieved http://www.flippedclassroomworkshop.com/best-practices-for-successful-flipped-classrooms-using-class-time/

Findlay-Thompson, S., \& Mombourquette, P. (2014). Evaluation of a flipped classroom in an undergraduate business course. Business Education \& Accreditation, 6(1), 63-71.

Giannakos, M. N., Krogstie, J., Sampson, D. (2018). Putting Flipped Classroom into Practice: A Comprehensive Review of Empirical Research. In: Sampson D., Ifenthaler D., Spector J., Isaías P. (eds) Digital Technologies: Sustainable Innovations for Improving Teaching and Learning. Springer, Cham. https://doi.org/10.1007/978-3-319-73417-0_2

Gu, X., Wu, B., \& Xu, X. (2014). Design, development, and learning in e-Textbooks: what we learned and where we are going. Journal of Computers in Education, 2(1), 25-41. https://doi.org/10.1007/s40692-014-0023-9

Gunawardhana, L. K., \& Palaniappan, S. (2016a). Possibility of using Multimedia Application for Learning. GSTF Journal on Computing, 5(1), 77-83. https://doi.org/10.7603/s40601-016-0012-0

Gunawardhana, L. K., \& Palaniappan, S. (2016b). Using Multimedia as an Education Tool. Retrieved https://www.academia.edu/24684294/Using_Multimedia_as_an_Education_Tool

Jackson, M. (2016). Gamification Elements to Use for Learning. Retrieved https://trainingindustry.com/content/uploads/2017/07/enspire_cs_gamification_2016.pdf 
Khaleel, F. L., Ashaari, N., Wook, T. S., \& Ismail, A. (2016). Gamification Elements for Learning Applications. International Journal on Advanced Science Engineering Information Technology, 6(6), 868-874. https://doi.org/10.18517/ijaseit.6.6.1379

Krotký, J., \& Honzíková, J. (2013). Evaluation and Analysis of the Multimedia Course Books and Their Didactic Parts. Journal of Education and Future, 4, 65-75.

Leutner, D. (2014). Motivation and emotion as mediators in multimedia learning. Learning and Instruction, 29, 174-175. https://doi.org/10.1016/j.learninstruc.2013.05.004

Norlis, O., Ramli, R. Z., \& Taib, J. M. (2018). Multimedia Education Tools for Effective Teaching and Learning. Journal of Telecommunication, Electronic and Computer Engineering, 9(2-8), 143-146.

Panopto. (2015). Engaging Your Students through Unconventional Teaching and Online Technology. Retrieved https://www.panopto.com/resource/practical-guide-to-flipped-classrooms/

Panopto. (2017). 7 Unique Flipped Classroom $\quad$ Models. $\quad$ Retrieved https://www.panopto.com/blog/7-unique-flipped-classroom-models-right/

Park, B., Plass, J. L., \& Brünken, R. (2014). Cognitive and affective processes in multimedia learning. Learning and Instruction, 29, 125-127. https://doi.org/10.1016/j.learninstruc.2013.05.005

Thamarana, S. (2016). Critical study of the use of interactive multimedia technologies in English classes. International journal of English language, literature and translation studies, 3(3), 50-54.

Udim, D. K. \& Etim, E. A. (2016). Use of multimedia in teaching and learning of political science in university of UYO, Akwa Ibon State, Nigeria. Research in Pedagogy, 6(2),154-170. https://doi.org/10.17810/2015.42

Wiginton, B. L. (2013). Flipped instruction: An investigation into the effect of learning environment on student self-efficacy, learning style, and academic achievement in an algebra I classroom. Doctoral dissertation. The University of Alabama.

Zhang, H., \& Yang, H. (2017). The Design and Realization of Multimedia Textbook The Equipment of Ship's Command and Control (C2) System. IOP Conf. Series: Journal of Physics: Conf. Series, 910, 012044. https://doi.org/10.1088/1742-6596/910/1/012044

Zhonggen, Y., \& Wang, G. (2016). Academic achievements and satisfaction of the clicker-aided flipped business English writing class. Journal of Educational Technology \& Society, 19(2), 298-312. 